\title{
Stressors affecting the macrobenthic community in Rapallo Harbour (Ligurian Sea, Italy)
}

\author{
ANABELLA COVAZZI HARRIAGUE, CRISTINA MISIC, MARIO PETRILLO \\ and GIANCARLO ALBERTELLI
}

DIP.TE.RIS. Dipartimento per lo Studio del Territorio e delle sue Risorse, Università di Genova, C.so Europa 26, 16132 Genova, Italy. E-mail: anabella7@ hotmail.com

\begin{abstract}
SUMMARY: An annual survey was carried out in Rapallo Harbour (Ligurian Sea, NW Mediterranean) to study the main stressors affecting the macrobenthic communities. The harbour was characterised by a relevant organic enrichment (between $51.9 \mathrm{mg} \mathrm{g}^{-1}$ and $109.6 \mathrm{mg} \mathrm{g}^{-1}$ ), which did not affect the water column oxygenation, and low but detectable heavy-metal contamination (on average $\mathrm{Cu}=135.0 \mu \mathrm{g} \mathrm{g}^{-1}$ and $\mathrm{V}=23.8 \mu \mathrm{g} \mathrm{g}^{-1}$ ). The seasonal changes in the heavy metal concentrations suggested a significant increase in tourist activities (i.e. boat movements) during summer and autumn. In the inner, more protected sampling site, the harbour structures and the vessel movements increased both organic enrichment and sediment instability, resulting in macrobenthic communities dominated by indicator species associated with these stressors. In addition, during summer and autumn, despite a relevant chlorophyll- $a$ flux to the sediment, the settling material was dominated by phaeopigments and refractory proteins, which reduced its trophic value for benthic consumers. In the outer part of the harbour the main stressor was a polluted freshwater inflow, as indicated by the dominance of indicator species such as Capitella spp. (on average 79.5\%), Neanthes caudata, Malacoceros girardi and Diopatra neapolitana.
\end{abstract}

Keywords: macrofauna, harbour, organic enrichment, trophic quality, stress indices, NW Mediterranean.

RESUMEN: FACTORES DE STRESS QUE AFECTAN A LAS COMUNIDADES MACROBENTÓNICAS EN EL PUERTO DE RAPALLO (MAR LiguRE, ITALIA). - Un muestreo se llevo a cabo durante un año en el puerto de Rapallo (Mar Ligure, NO Mediterráneo) para estudiar los factores principales que afectan a las comunidades macrobentónicas. El puerto presentó un notable enriquecimiento orgánico (entre $51.9 \mathrm{mg} \mathrm{g}^{-1}$ y $109.6 \mathrm{mg} \mathrm{g}^{-1}$ ), que no disminuyó la oxigenación del agua, y una baja pero detectable contaminación de metales pesados (en promedio $\mathrm{Cu}=135.0 \mu \mathrm{g} \mathrm{g}^{-1} \mathrm{y} \mathrm{V}=23.8 \mu \mathrm{g} \mathrm{g}^{-1}$ ). Las variaciones estacionales en la concentración de metales pesados sugirieron un aumento significativo de las actividades turísticas (i.e. movimiento de las embarcaciones) durante el verano y el otoño. En la parte interna, más protegida, las infraestructuras del puerto y el movimiento de los barcos incrementaron el enriquecimiento orgánico y la inestabilidad del sedimento, favoreciendo la dominancia en las comunidades macrobéntonicas de especies indicadoras asociadas a dichos factores de stress. Además, durante el verano y el otoño, no obstante el relevante flujo de clorofila- $a$, el material sedimentado estuvo dominado por feopigmentos y proteínas refractarias, reduciendo su valor trófico para los consumidores bentónicos. En la parte externa del puerto, el principal factor de stress fue el torrente, como lo confirmara la dominancia de especies indicadoras tales como Capitella spp. (en promedio $79.5 \%)$, Neanthes caudata, Malacoceros girardi y Diopatra neapolitana.

Palabras claves: macrofauna, puerto, enriquecimiento orgánico, índices de stress, NO Mediterráneo.

\section{INTRODUCTION}

Increasing recreational and commercial activity along the coast have dramatically changed the littoral environment and influenced the development of coastal communities. An example of anthro- pogenic pressure on the coastal zone is represented by harbours. Harbours are enclosed areas characterised by high sediment pollution levels (due to contaminants such as heavy metals, petroleum and pesticides (Blanchard et al., 2003; Je et al., 2003; Caplat et al., 2005)) and huge organic matter loads 
(Caplat et al., 2005). Furthermore, the low hydrodynamism (Danulat et al., 2002) and generally poor oxygenation of the water column (Guerra García and García Gómez, 2005) lead to a limited diversification of benthic communities (Estacio et al., 1997). There have been less studies of the macrofauna of harbours than of other shallow-water environments. However, it is well known that the fauna within harbours is generally suffering and impoverished (Estacio et al., 1997).

Macrobenthos is a useful descriptor of the environment, which integrates both changes and conditions over a period of time rather than just reflecting those at the sampling time (Warwick et al., 1990). Environmental disturbances may cause structural changes in benthic assemblages, which influence species diversity (Gray and Pearson, 1982; Rygg, 1985), due to different species' stress tolerances (Dauer et al., 1993). Tolerant or opportunistic species tend to dominate stressed assemblages and less tolerant species tend to become increasingly rare or disappear. Therefore, both of these species can serve as stress indicators (Belan, 2003). The former could be regarded as positive pollution indicators, and the latter may be considered as negative indicators.

Rapallo Harbour is the largest tourist harbour in the Marconi Gulf (Ligurian Sea, NW Mediterranean). The harbour is mainly affected by wastewaters, urban runoff and marine activities (recreational fishing, tourism and related vessel maintenance). The aim of this study is to highlight the environmental stressors affecting the macrofaunal communities in the harbour by analysing their spatial and temporal patterns.

\section{MATERIAL AND METHODS}

\section{Study site}

Rapallo Harbour is the largest tourist harbour in the Marconi Gulf, and is divided into two basins: the public port and the private Carlo Riva International Tourist Port (Fig. 1). The dominant coastal current enters from the east, generating feeble internal circulation from the public (4 m deep maximum) to the private sector ( $9 \mathrm{~m}$ deep), which was built to facilitate the movement and mooring of large recreational vessels. The Boate Torrent (generally carrying coarse organic and inorganic

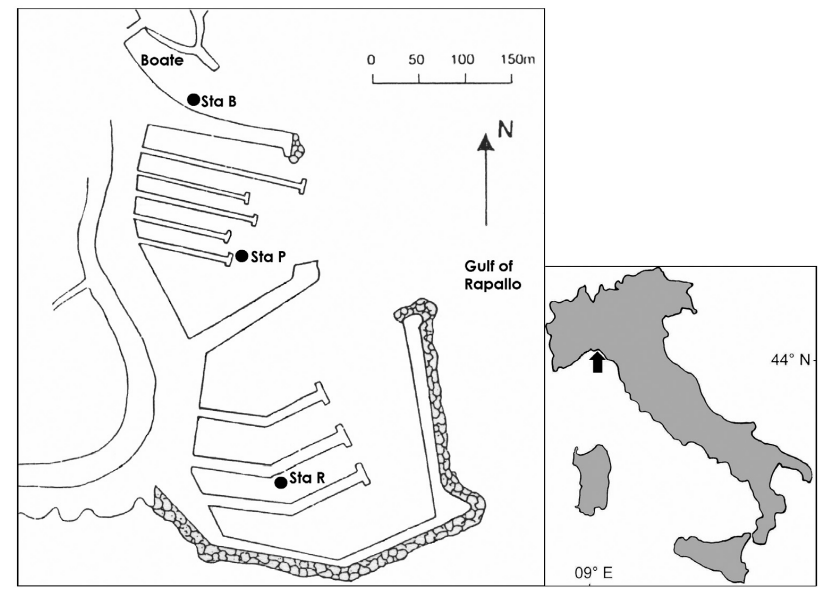

FIG. 1. - Sampling stations in Rapallo Harbour.

debris, and used seasonally for mooring small recreational boats) discharges into the northern part of the harbour, which is protected from the massive entrance of fresh water by a concrete pier. About $40 \%$ of the sediments at the mouth of the stream have a grain size smaller than $0.063 \mathrm{~mm}$, while in the public and private port areas the silt and clay fraction $(<0.063 \mathrm{~mm})$ is dominant, $95.7 \%$ and $88.7 \%$ respectively $(\mathrm{C}$. Siccardi and R. Capelli, personal communication).

The harbour and the Boate Torrent receive surface runoff and uncontrolled wastewaters, both municipal and from small factories and farms situated along the $1.9 \mathrm{~km}$ course of the stream. Allochthonous inputs increased during the 1990s due to an increase in the permanent and tourist population (3.3\%). The Province of Genoa (1996) reported a decrease in the Extended Biological Index (E.B.I.), from 11 (1991) to 7 (1995), which indicates increasing contamination of the stream.

The sediments of Rapallo Harbour (sampling was performed at the same times and at the same stations as the macrofaunal study - see Sampling section for further details) showed a moderately high level of trace metals (C. Siccardi and R. Capelli, personal communication), with $\mathrm{Cu}$ and $\mathrm{V}$ trends linked to seasonal tourist traffic (Table 1). In particular, the summer-autumn $\mathrm{V}$ content was significantly higher $(t$-test, $\mathrm{p}<0.01)$ than the winterspring one.

\section{Sampling}

Sediment samples were collected seasonally (February, April, August and October 1997, that is 
TABLE 1. - Sediment content ( \pm standard deviation) of copper and vanadium $\left(\mu \mathrm{g} \mathrm{g}^{-1}\right)$ (data provided by C. Siccardi and R. Capelli, University of Genoa).

\begin{tabular}{llccc}
\hline $\begin{array}{l}\text { trace } \\
\text { metal }\end{array}$ & $\begin{array}{l}\text { sampling } \\
\text { season }\end{array}$ & $\begin{array}{c}\text { Station } \\
\text { B }\end{array}$ & $\begin{array}{c}\text { Station } \\
\text { P }\end{array}$ & $\begin{array}{c}\text { Station } \\
\text { R }\end{array}$ \\
\hline $\mathrm{Cu}$ & winter & $67 \pm 13$ & $163 \pm 58$ & $135 \pm 19$ \\
& spring & $73 \pm 7$ & $150 \pm 35$ & $135 \pm 17$ \\
& summer & $218 \pm 31$ & $151 \pm 39$ & $126 \pm 11$ \\
& autumn & $134 \pm 19$ & $132 \pm 32$ & $136 \pm 21$ \\
$\mathrm{~V}$ & winter & $17 \pm 4$ & $21 \pm 5$ & $25 \pm 2$ \\
& spring & $11 \pm 2$ & $17 \pm 4$ & $25 \pm 3$ \\
& summer & $28 \pm 5$ & $27 \pm 6$ & $36 \pm 4$ \\
& autumn & $24 \pm 2$ & $25 \pm 5$ & $30 \pm 2$ \\
\hline
\end{tabular}

winter, spring, summer and autumn) at three stations inside the harbour (Fig. 1): Station P (3 m deep) in the public area; Station R (7 m deep) in the Carlo Riva area; Station B (1.5 m deep) in the outer part of the harbour, at the mouth of the Boate Torrent near the area used seasonally for mooring small boats.

Ten sediment samples were collected from each station using a modified Van Veen grab (surface area $216 \mathrm{~cm}^{2}$ ). The macrofauna was sieved through a 0.5 $\mathrm{mm}$ mesh and fixed in $10 \%$ neutralised formalin. Surface sediment was collected for determining organic matter content and stored at $-20^{\circ} \mathrm{C}$ until analysed. The dissolved oxygen concentration was measured on each sampling occasion.

From January to December a sediment trap (20 $\mathrm{cm}$ diameter) was deployed each week at Station P. The trap was kept on the bottom for 10-12 hours each night and retrieved at dawn, thus avoiding resuspension phenomena due to the movement of small boats during the day. Due to the short time of deployment no preservative chemicals were added. After retrieval, the samples (1 1 total volume) were immediately taken to the lab, prefiltered through a $200 \mu \mathrm{m}$ mesh and divided into subsamples in order to determine the total settling matter and its organic fraction, the main biochemical composition (proteins and carbohydrates), and the autotrophic contribution (chlorophyll- $a$ and phaeopigments) to the flux. The environmental parameters were recorded during each trap deployment. Sky coverage was determined by eye and bottom water temperature and salinity were determined with an Aandera Mod. 3315 probe.

\section{Laboratory procedures}

The total organic matter content was estimated using the gravimetric method, using a Mettler M3 $\left( \pm 10 \mu \mathrm{g}\right.$ accuracy), after desiccation $\left(60^{\circ} \mathrm{C}\right.$ for 12 hours) and calcination $\left(550^{\circ} \mathrm{C}\right.$ for 4 hours). Dissolved oxygen was determined following Carpenter (1965).

The sediment trap subsamples (from 30 to 100 $\mathrm{ml}$ each) were filtered through Whatman GF/F filters (pore diameter $0.8 \mu \mathrm{m}$ ). Then the filters were processed (in triplicate) as described below.

The total suspended matter and its organic fraction were determined according to the gravimetric method. The chlorophyll- $a$ and phaeopigment contents were determined following Lorentzen (1967). The protein and carbohydrate contents were determined following Hartree (1972) and Dubois et al. (1956) respectively. The pigment and biochemical composition analyses were carried out using a Varian DSM90 spectrophotometer. The specific standard deviation between the three replicates was never higher than $15 \%$ for any analysis.

The macrofaunal organisms were recognised to species level. The molluscs were treated with $30 \%$ $\mathrm{HCl}$ prior to weighing all the organisms to obtain the biomass value expressed as AFDW $\left(550^{\circ} \mathrm{C}\right.$ for $4 \mathrm{~h}$ in a muffle furnace after oven-drying at $60^{\circ} \mathrm{C}$ for $24 \mathrm{~h}$ ).

\section{Statistical analysis}

The results of the suspended matter fluxes and environmental data were averaged for each month. The mean values were compared using the BrayCurtis similarity index (based on fourth root transformed data) and the cluster analysis of the PRIMER package (Clarke, 1990; Clarke and Warwick, 1994). A Spearman rank-correlation analysis was performed to test the relationships between the various parameters. Student's $t$-test was used to verify significant differences within single parameters. For the flux parameters we considered summer-autumn to be the period from June to November and winter-spring to be the period from January to May and December.

The abundance data (calculated as the average of the 10 replicates) were compared using the BrayCurtis similarity index (based on fourth root transformed data). The species diversity (H', log base 2) and evenness (J) were calculated. ABC curves (abundance biomass comparisons) were used to investigate community stress. All statistical analyses were also performed with corresponding routines of the PRIMER package. 


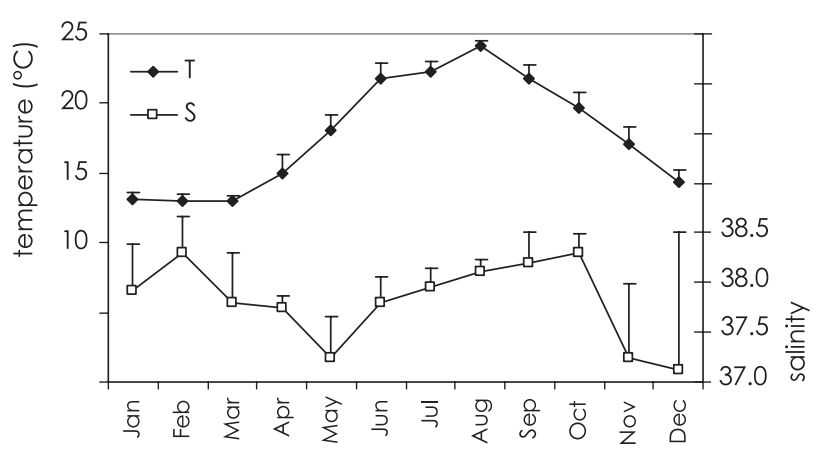

FIG. 2. - Bottom water temperature $\left({ }^{\circ} \mathrm{C}\right)$ and monthly salinity trends at Station P. Bars denote the standard deviations.

The marine biotic coefficient (BC) was calculated using the AMBI programme available from AZTI's website (http://www.azti.es). The BC value ranged from 0 (unpolluted) to 6 (heavily polluted), reaching 7 (extremely polluted) when the community's health was defined as azoic (Borja et al., 2000).

\section{RESULTS}

\section{Environmental features}

The bottom water temperature at Station $\mathrm{P}$ showed a typical seasonal trend (Fig. 2) with the lowest value $\left(12.4^{\circ} \mathrm{C}\right)$ during February and the highest $\left(24.7^{\circ} \mathrm{C}\right)$ during August. Low water temperatures were recorded until March (on average $13.0^{\circ} \mathrm{C}$ ), while temperatures higher than $20^{\circ} \mathrm{C}$ were recorded from June to September. Salinity values showed a strong reduction during May, November and December, falling to 37.1-37.2 (Fig. 2). The highest values were recorded from July to October (more than 38). The significant, inverse correlation between the mean monthly values for salinity and sky coverage $(r=-0.61, n=12$, $\mathrm{p}<0.05)$ suggests the strong influence of the raindependent stream in regulating the physical features of the water column.

The dissolved oxygen concentration of the bottom water was highest at Station $\mathrm{P}$ (on average 8.2 $\mathrm{mg}^{-1}$ ) and lowest at Station B (on average $7.0 \mathrm{mg}$ $\left.1^{-1}\right)$. The maximum values at all sites occurred in spring $\left(8.1,9.3\right.$ and $9.1 \mathrm{mg} \mathrm{l}^{-1}$ for Station B, Station $\mathrm{P}$ and Station $\mathrm{R}$ respectively), and the minimum values at Station B in summer and autumn $\left(6.4 \mathrm{mg} \mathrm{l}^{-1}\right)$, at Station $\mathrm{P}$ in autumn $\left(7.0 \mathrm{mg}^{-1}\right)$ and at Station $\mathrm{R}$ in winter $\left(6.9 \mathrm{mg} \mathrm{l}^{-1}\right)$.

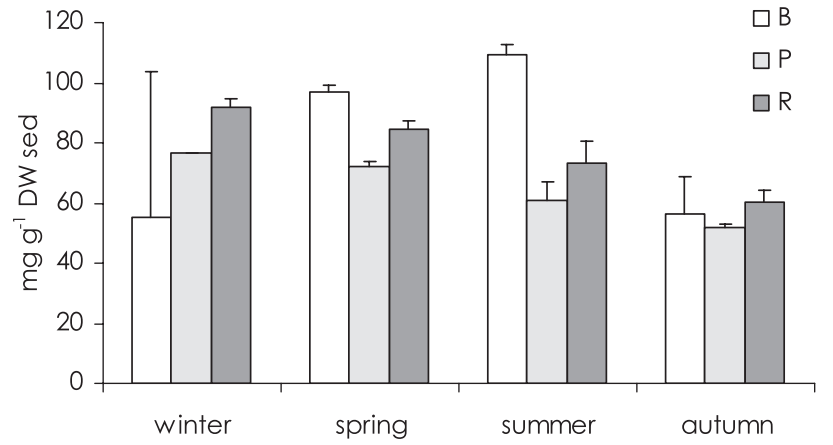

FIG. 3. - Seasonal data of total organic matter content $\left(\mathrm{mg} \mathrm{g}^{-1}\right)$ at the three sites in Rapallo Harbour.

\section{Sediment organic matter and suspended matter flux}

The total organic matter content of the sediment (Fig. 3) decreased inside the harbour from winter to autumn. Station $\mathrm{R}$ had the highest values (on average $77.5 \pm 11.9 \mathrm{mg} \mathrm{g}^{-1}$ vs. $65.4 \pm 9.6 \mathrm{mg} \mathrm{g}^{-1}$ at Station P). Station B showed an increase from winter to summer (up to $109.6 \pm 2.9 \mathrm{mg} \mathrm{g}^{-1}$ ) and a decrease in autumn.

Despite the strong monthly fluctuations, the gross average monthly sedimentation (TSM, Fig. 4A) increased from January (738.2 $\mathrm{mg} \mathrm{m}^{-2} \mathrm{~h}^{-1}$ ) to October $\left(1390.1 \mathrm{mg} \mathrm{m}^{-2} \mathrm{~h}^{-1}\right)$. The organic fraction of the gross flux (OSM, Fig. 4A), however, increased only until July (from 177.6 to 359.1 $\mathrm{mg} \mathrm{m}^{-2} \mathrm{~h}^{-1}$ ), and then decreased to December (down to $221.1 \mathrm{mg} \mathrm{m}^{-2} \mathrm{~h}^{-1}$ ), with an average contribution to the gross flux of $27.7 \%$ (higher than $30 \%$ during June and July). Highly significant increases from the winter-spring to the summerautumn period were recorded for both TSM and OSM ( $t$-tests, $\mathrm{p}<0.001)$, with mean values of 870.4 and $1199.0 \mathrm{mg} \mathrm{m}^{-2} \mathrm{~h}^{-1}$ for TSM and 252.1 and $325.3 \mathrm{mg} \mathrm{m}^{-2} \mathrm{~h}^{-1}$ for OSM respectively for winterspring and summer-autumn.

The significant correlation between the OSM and the chlorophyll $-a$ content $(\mathrm{r}=0.59, \mathrm{n}=12, \mathrm{p}<0.05)$ suggests that the OSM was dependent on the primary biomass. The chlorophyll- $a$, in fact, peaked in summer (June-September), with values up to 43.9 $\mu \mathrm{g} \mathrm{m}^{-2} \mathrm{~h}^{-1}$ during July (Fig. 4B). The chlorophyll-a flux was significantly higher in summer-autumn $(25.6$ $\left.\mu \mathrm{g} \mathrm{m}^{-2} \mathrm{~h}^{-1}\right)$ than in winter-spring $\left(17.9 \mu \mathrm{g} \mathrm{m}^{-2} \mathrm{~h}^{-1}\right)$ $(t$-test, $\mathrm{p}=0.03)$. The phaeopigments increased remarkably during autumn to values up to 105.4 $\mu \mathrm{g} \mathrm{m}^{-2} \mathrm{~h}^{-1}$ in September (Fig. 4B), and the average monthly values correlated significantly with the 
TSM $(\mathrm{r}=0.75, \mathrm{n}=12, \mathrm{p}<0.01)$. The phaeopigment flux of the winter-spring period $\left(12.9 \mu \mathrm{g} \mathrm{m}^{-2} \mathrm{~h}^{-1}\right)$ was significantly lower $(t$-tests, $\mathrm{p}<0.001)$ than that of summer-autumn $\left(57.9 \mu \mathrm{g} \mathrm{m}^{-2} \mathrm{~h}^{-1}\right)$.

The chlorophyll-a:phaeopigment ratio, which is a rough estimate of phytoplanktonic activity (the higher the ratio value, the higher the activity), was significantly higher $(t$-test, $\mathrm{p}<0.001)$ during winterspring (1.7) than summer-autumn (0.7), which suggests that maximum production occurred during winter and spring (especially February, April and December).
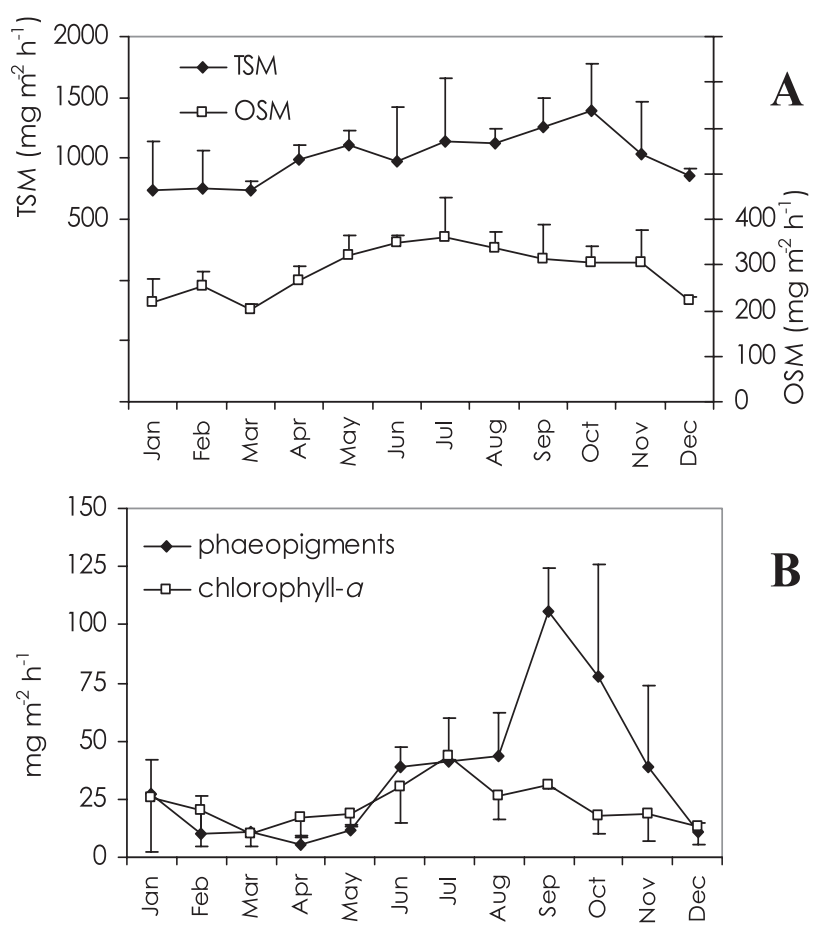

B

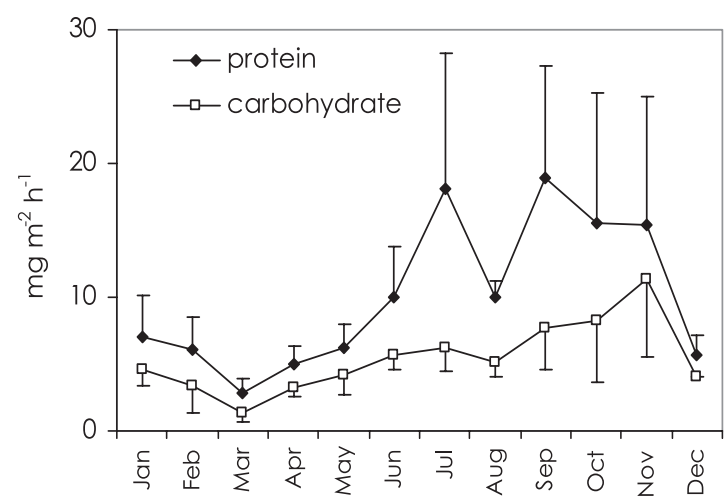

FIG. 4. - Flux composition at Station P. A: total suspended matter (TSM) and suspended organic matter (OSM) $\left(\mathrm{mg} \mathrm{m}^{-2} \mathrm{~h}^{-1}\right)$; B: chlorophyll- $a$ and phaeopigment content $\left(\mu \mathrm{g} \mathrm{m}^{-2} \mathrm{~h}^{-1}\right) ; \mathrm{C}$ : protein and carbohydrate content $\left(\mathrm{mg} \mathrm{m}^{-2} \mathrm{~h}^{-1}\right)$. Data, collected weekly, were averaged for each month. Bars denote the standard deviation between the different results for each month.

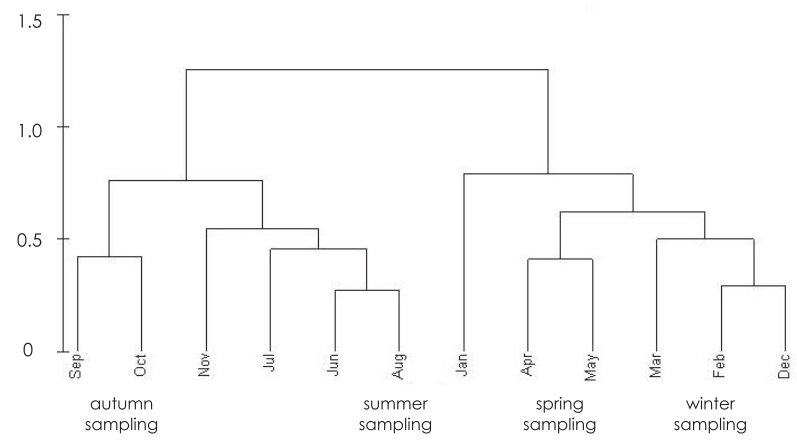

FIG. 5. - Cluster analysis applied to average monthly values of suspended matter fluxes and environmental data.

The protein content of the flux (Fig. 4C) was significantly higher during summer-autumn ( $t$-test, $\mathrm{p}<0.001)$ than winter-spring, although subject to notable monthly variability. The carbohydrate content of the flux (Fig. 4C) was also significantly higher in the summer-autumn period ( $t$-test, $\mathrm{p}<0.001)$ but the values were always lower than those of the protein. While the protein content correlated significantly with all the parameters (in particular with the chlorophyll- $a \mathrm{r}=0.66, \mathrm{n}=12, \mathrm{p}<0.05)$, the carbohydrates were significantly correlated only with TSM and phaeopigments ( $\mathrm{r}=0.66$ and $\mathrm{r}=0.62$ respectively, $\mathrm{n}=12, \mathrm{p}<0.05)$. Moreover, we observed a slight but significant decrease in the sedimentary organic matter $(\mathrm{r}=-0.98, \mathrm{n}=4, \mathrm{p}<0.05$, flux values seasonally averaged at the same time as the increase in the total suspended matter flux in the water).

The flux features were similar in summerautumn (from June to November) and in winterspring (from January to May and December) respectively (Fig. 5). The SIMPER analysis demonstrated that the phaeopigments were by far the most significant discriminating parameter, explaining more than $50 \%$ of the difference, followed by TSM (14\%) and proteins $(12 \%)$.

\section{Macrofauna}

\section{Structure and function of the macrobenthic community}

The density of the macrobenthos in Rapallo Harbour decreased from winter to autumn, particularly at the mouth of the Boate Torrent (Table 2). The maximum value was observed at Station B during winter and the minimum at the same station during autumn. On average, Station P and Station R had similar densities, approximately half of that at 
TABLE 2. - Seasonal data of the macrofaunal communities at the three sites in Rapallo Harbour: density (D, ind. $\left.\mathrm{m}^{-2}\right)$ and biomass $(\mathrm{B}$, mgAFDW $\mathrm{m}^{-2}$ ) of each group, and species number $(\mathrm{N})$.

\begin{tabular}{|c|c|c|c|c|c|c|c|c|c|c|}
\hline & & Crus & & Polyc & aeta & $\mathrm{Mol}$ & & & & $\mathrm{N}$ \\
\hline & & D & B & D & B & $\mathrm{D}$ & B & $\mathrm{D}$ & B & \\
\hline B & $\begin{array}{l}\text { winter } \\
\text { spring }\end{array}$ & $55.6 \pm 81.1$ & $3.4 \pm 4.2$ & $\begin{array}{l}1847.2 \pm 847.6 \\
18287+5360\end{array}$ & $376.3 \pm 171.8$ & $13.9 \pm 31.2$ & $234.4 \pm 327.4$ & $18.5 \pm 44.7$ & $268.8 \pm 329.2$ & 14 \\
\hline & summer & & & $217.6 \pm 226.7$ & $105.4 \pm 108.7$ & $2.3 \pm 10.4$ & $26.6 \pm 98.3$ & & & $\begin{array}{l}10 \\
14\end{array}$ \\
\hline & autumn & & & $101.9 \pm 100.5$ & $68.9 \pm 61.3$ & $9.3 \pm 19.5$ & $214.3 \pm 412.8$ & & & 9 \\
\hline $\mathrm{P}$ & winter & $13.9 \pm 31.2$ & $1.2 \pm 2.7$ & $754.6 \pm 345.5$ & $266.7 \pm 134.9$ & $50.9 \pm 73.8$ & $199.3 \pm 289.0$ & & & 35 \\
\hline & spring & $32.4 \pm 43.9$ & $1.8 \pm 2.4$ & $287.0 \pm 120.1$ & $70.7 \pm 27.5$ & $18.5 \pm 32.4$ & $26.7 \pm 46.7$ & $9.3 \pm 19.5$ & $16.2 \pm 34.2$ & 20 \\
\hline & summer & $4.6 \pm 14.2$ & $0.3 \pm 0.8$ & $268.5 \pm 185.9$ & $96.5 \pm 63.2$ & $2.3 \pm 10.4$ & $52.2 \pm 200.4$ & & & \\
\hline & autumn & & & $217.6 \pm 171.9$ & $125.1 \pm 96.3$ & & & $4.6 \pm 14.6$ & $98.5 \pm 305.4$ & 13 \\
\hline $\mathrm{R}$ & winter & $9.3 \pm 19.5$ & $0.2 \pm 0.4$ & $560.2 \pm 381.2$ & $52.0 \pm 31.7$ & $92.6 \pm 84.5$ & $137.4 \pm 119.5$ & & & \\
\hline & spring & & & $486.1 \pm 331.6$ & $76.3 \pm 50.6$ & $46.3 \pm 43.6$ & $41.8 \pm 29.4$ & $4.6 \pm 14.6$ & $7.9 \pm 25.1$ & 10 \\
\hline & summer & $11.6 \pm 25.5$ & $0.5 \pm 0.9$ & $289.4 \pm 167.4$ & $56.0 \pm 31.6$ & $64.8 \pm 66.2$ & $94.7 \pm 89.7$ & & & \\
\hline & autumn & & & $310.2 \pm 89.5$ & $26.1 \pm 6.9$ & $23.1 \pm 24.4$ & $11.5 \pm 9.1$ & $4.6 \pm 14.6$ & $2.7 \pm 5.1$ & 10 \\
\hline
\end{tabular}

Station B. Polychaetes dominated the communities (on average $91.6 \%$ ) at all stations and in all seasons, followed by molluscs (on average 5.9\%), which were particularly well represented at Station $\mathrm{R}$ in summer.

The number of species was higher at Station $\mathrm{P}$ and showed a decreasing pattern from winter to autumn. At Stations B and R, the number of species was quite similar (on average 12 and 13 respectively). Shannon diversity (H') and evenness (J) showed the maximum values at Station P, 3.9 (winter) and 0.8 (spring) for $\mathrm{H}^{\prime}$ and $\mathrm{J}$ respectively (Fig. 6). The minimum values were observed at Station B in winter ( 0.6 and 0.16 for $\mathrm{H}^{\prime}$ and $\mathrm{J}$ respectively). On average Station $\mathrm{P}$ presented the highest diversity and evenness (3.3 and 0.7 respectively), followed by Station R (2.5 and 0.7 respectively) and Station B (1.6 and 0.45 respectively).

The total biomass reached its highest values at all sites in winter (Table 2). On the whole, polychaetes made the main contribution to the total biomass $(50.7 \%)$, followed by molluscs $(35.5 \%)$. Similar

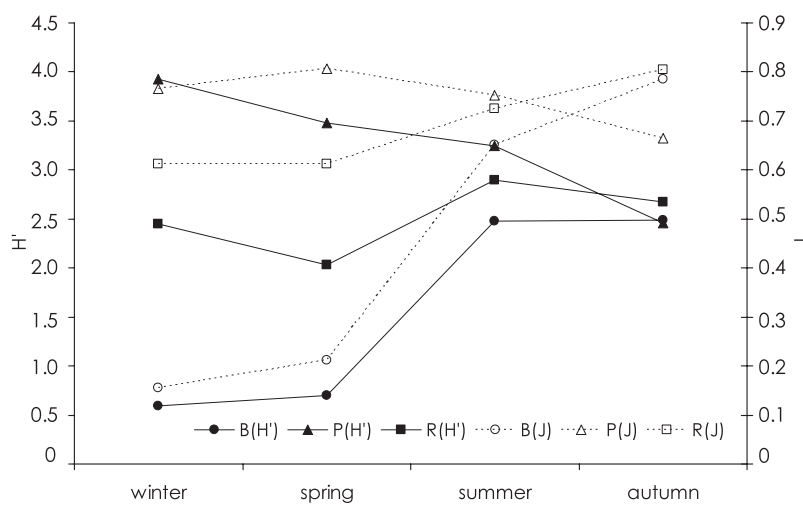

FIG. 6. - Seasonal Shannon-Weaver's diversity (H') and evenness (J) trends. biomass values were found at Station $\mathrm{P}$ and Station $\mathrm{B}$, while at Station R molluscs made the major contribution to the biomass (56.3\%), followed by polychaetes $(41.5 \%)$. Deposit-feeders numerically dominated the Rapallo Harbour communities (on average $81.8 \%$ ), followed by organisms with a mixed trophic strategy $(6.8 \%)$, predators $(6.6 \%)$ and suspension-feeders $(2.9 \%)$.

\section{Stress indices of the benthic community}

The structure of the communities in the inner part of the harbour (Groups I and II) (Fig. 7) clearly differed (SIMPER analysis, dissimilarity $=81.1 \%$ ) from that of the community at the mouth of the Boate Torrent (Group III) (Fig. 7), mainly due to the occurrence of pollution indicator species at the mouth of the stream that were absent from (e.g. Neanthes caudata and Malacoceros giradi) or poorly represented (Capitella spp.) at the inner stations. Inside the har-

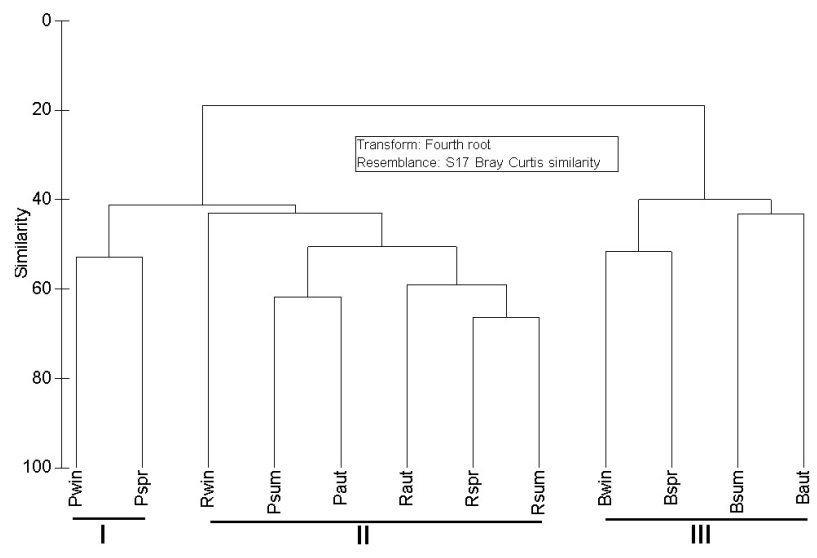

FIG. 7. - Cluster analysis of the macrofauna density. $\mathrm{P}=$ Station $\mathrm{P}$, $\mathrm{B}=$ Station $\mathrm{B}, \mathrm{R}=$ Station $\mathrm{R}$, win $=$ winter, $\mathrm{spr}=$ spring, sum $=$ summer and aut $=$ autumn . 


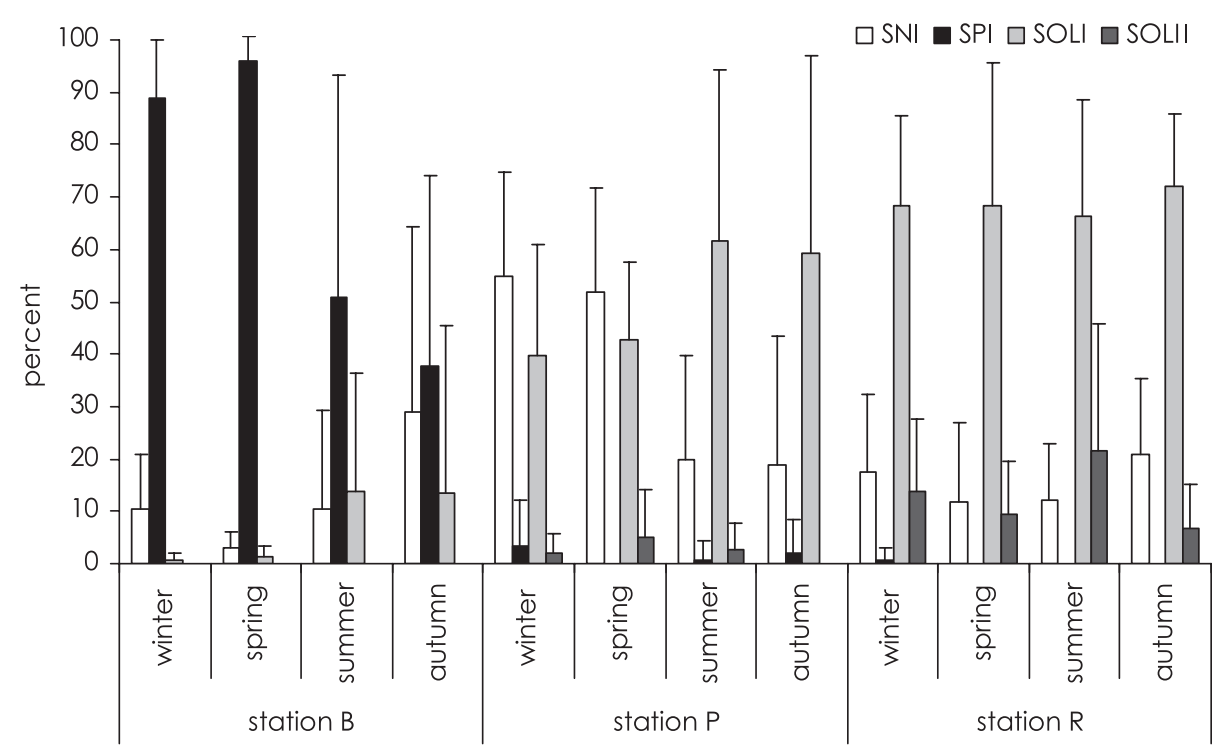

FIG. 8. - Seasonal density trend of the bionomic groups as a percentage: negative species indicator (SNI), species pollution indicator (SPI), organic load indicator species (SOLI) and organic load and instability indicator species (SOLII).

bour, Group I represented the communities at Station $\mathrm{P}$ in winter and spring, and was characterised by the highest number of species, the highest abundance of negative indicator species and largest diversity and evenness (Fig. 8). Group II represented all the other samples at Stations $\mathrm{P}$ and $\mathrm{R}$, which had similar densities and community compositions.

The species composition highlighted the massive presence of the indicator species at all sites (Fig. 8). Station B was characterised by the dominance of the pollution indicators Malacoceros giradi, Diopatra neapolitana, Neanthes caudata and, in particular, Capitella spp. (on average $79.5 \%$ ), while the negative indicator species represented $10.5 \%$ on average. Station $\mathrm{P}$ was dominated by organic load indicators (Chaetozone setosa, Cirriformia tentaculata, Cirrineris incertus, Caulleriella alata, Aonides oxycephala, Nephthys hombergi and Prionospio cirrifera, on average $60.3 \%$ ) and by organic load and instability indicators (Corbula gibba, Aphelochaeta marioni and Lumbrineris emandibulata mabiti). The negative indicator species were dominant in winter and spring and well represented in the other seasons (on average $35.4 \%$ ). At Station R, the organic load indicators (Aphelochaeta marioni, Chaetozone setosa, Ciriformia tentaculata, Cirrineris incertus, Caulleriella alata, Aonides oxycephala, Nephthys hombergi and Prionospio cirrifera), the organic load and instability indicators (Corbula gibba and Lumbrineris emandibulata mabiti) and the negative indicators reached 73.4, 12.2 and $14.2 \%$ respectively (Fig. 8).
Depending on the site and season, the community disturbance index ranged from slight (W close to 0.2 ) to severe (W negative) disturbance to the communities. The situation was particularly critical at Station R in spring and at Station B in winter (Table $3)$. Station $P$ showed no seasonality, being moderately disturbed all year round, while Station R was moderately disturbed in autumn and winter, slightly disturbed in summer, and severely disturbed in spring. Station B was severely disturbed from winter to summer (W values under 0 ) and slightly disturbed in autumn.

The marine biotic coefficient (Table 3) was highest at Station B during all seasons, representing a "heavily polluted" overall condition (5.1), while the

TABLE 3. - Results of the marine biotic coefficient and W statistics (ABC curves) calculated for the sampling sites in Rapallo Harbour. AMBI biotic coefficients: HP - heavily polluted, MP - meanly polluted, SP - slightly polluted. For W statistics of ABC: SD - severely disturbed, MD - moderately disturbed, PD - slightly disturbed.

\begin{tabular}{llccc}
\hline & & Station B & Station P & Station R \\
\hline \multirow{2}{*}{ Winter } & AMBI & $5.92(\mathrm{HP})$ & $3.55(\mathrm{MP})$ & $3.86(\mathrm{MP})$ \\
& W (ABC) & $-0.10(\mathrm{SD})$ & $0.08(\mathrm{MD})$ & $0.15(\mathrm{MD})$ \\
\multirow{5}{*}{ Spring } & AMBI & $5.84(\mathrm{HP})$ & $3.10(\mathrm{SP})$ & $4.07(\mathrm{MP})$ \\
& W (ABC) & $-0.01(\mathrm{SD})$ & $0.07(\mathrm{MD})$ & $-0.16(\mathrm{SD})$ \\
Summer & AMBI & $4.26(\mathrm{MP})$ & $3.58(\mathrm{MP})$ & $3.87(\mathrm{MP})$ \\
& W (ABC) & $-0.02(\mathrm{SD})$ & $0.10(\mathrm{MD})$ & $0.21(\mathrm{PD})$ \\
Autumn & AMBI & $4.50(\mathrm{MP})$ & $4.15(\mathrm{MP})$ & $3.64(\mathrm{MP})$ \\
& W (ABC) & $0.24(\mathrm{PD})$ & $0.15(\mathrm{MD})$ & $0.004(\mathrm{MD})$ \\
Global & AMBI & $5.13(\mathrm{HP})$ & $3.59(\mathrm{MP})$ & $3.86(\mathrm{MP})$ \\
& W (ABC) & $-0.11(\mathrm{SD})$ & 0.03 (MD) & $0.07(\mathrm{MD})$ \\
\hline & & & &
\end{tabular}


overall situation was "moderately polluted" at the stations inside the harbour (Station $\mathrm{P}=3.6$ and Station $\mathrm{R}=3.9$ ).

\section{DISCUSSION}

Harbours habitually show high organic matter inputs due to the increasing sedimentation caused by port structures (Danulat et al., 2003). Accordingly, the sediments at Rapallo Harbour had a higher organic matter content than adjacent Ligurian softbottoms, such as the estuary of the Entella River (Albertelli et al., 1999) and the Posidonia meadows of Prelo (Covazzi Harriague et al., 2006). Compared to other Mediterranean harbours, the organic content was higher than that of the Port of Ceuta (Guerra García and García Gómez, 2005) and similar to that of the Port-en-Bessin (Seine Bay, NW France), which is considered to be heavily organically polluted (Caplat et al., 2005).

Nevertheless, the bottom water of Rapallo Harbour was always well oxygenated, similarly to the Port of Ceuta, whose structures allow constant water exchange (Guerra García and García Gómez, 2005). Due to its limited size Rapallo Harbour allows internal circulation that is strong enough to oxygenate the water at Station $\mathrm{R}$ inside the harbour. These high oxygen values were probably due to the shallowness of the zone, combined with the strong vertical mixing caused by the maritime traffic (Varela and Prego, 2003).

The heavy-metal content was correlated to the human activities of Rapallo Harbour. The $\mathrm{Cu}$ content of Rapallo Harbour sediments was 4 to 11 times higher than that of New Zealand estuaries (Morrisey et al., 2003), but was one order of magnitude lower than that recorded in harbours polluted by heavymetals (Caplat et al., 2005). The Cu content of the sediments, known to be related to hull-cleaning activities (Schiff et al., 2004), in Rapallo Harbour was constant at the stations where recreational boats were permanently moored and increased notably during the tourist season at Station B, where small boats were mainly only moored during summer and autumn. The seasonal increase in boat activity coincided with a significantly higher sediment content of $\mathrm{V}$ in summer and autumn, as this metal is a typical hydrocarbon by-product (Censi et al., 2006).

On the whole, the stress indicators (diversity and evenness indices, $\mathrm{ABC}$ curves and marine biotic coefficient) indicated communities that were moderately to severely disturbed, as confirmed by the lack of and/or limited development of sensitive taxa such as echinoderms and amphipods (Blanchard et al., 2002, 2003). However, the stress factors seemed to be different. The multivariate analysis indicated a high similarity between Station $\mathrm{P}$ and Station R, where the assemblages seemed to respond to the effects of the port structures and activities. Station B, however, seemed to be affected by the stream's discharges.

Station R was moderately polluted in all seasons and suffered more or less constant stress throughout the year, as indicated by the high frequency and importance of opportunistic taxa. The apparent increase in all indices in summer (the period of the maximum anthropic disturbance) was probably due to the decrease in the abundance, while the number of species and the biomass remained constant.

At Station R, the seasonal vessel movement probably constituted a notable factor influencing infaunal community structure, as the organic load and instability indicators were much more abundant in summer, when the tourist traffic increased. Blanchard et al. (2003) reported a similar macrofaunal re-adjustment in Port Valdez. More specifically, the transit of big boats (from 10 to $40 \mathrm{~m}$ long) caused an increase in turbulence and, consequently, in sedimentary movements at Station R.

At the other internal site (Station P) the response of the macrobenthos indicated relatively low stress during winter and spring, in accordance with the lower tourist traffic. In these periods the macrofaunal assemblages showed high diversity and evenness, the communities were dominated by negative organic matter load indicators and had their lowest biotic coefficients. In summer, however, the community was dominated by organic load indicator species and the diversity was lower.

The chlorophyll- $a$ flux to the sediment was similar in spring and summer, suggesting that a continuous supply of nutrients should have been available for the phytoplankton throughout the entire year, therefore generating a particular phytoplankton cycle as observed in A Coruña Harbour (NW Spain) (Varela and Prego, 2003). However, this flux was lower than those observed during the spring bloom in eutrophic coastal zones of the Baltic Sea subjected to river influence (Tamelander and Heiskanen, 2004) and of coastal areas of Japan (Suo Sound, Yamaguchi et al., 2003), which suggests that 
Rapallo Harbour is not highly eutrophicated. In fact, the dissolved oxygen concentrations were high, probably due to an increase in phytoplanktonic photosynthesis during winter and spring.

Although the chlorophyll- $a$ flux was higher at Station P in summer than in spring, the organic matter flux to the sediment was richer in settling detrital particles in the summer-autumn period than in winter-spring. This adds an ecological bottom-up environmental control that regulates the macrobenthic communities. It is worth noting that the protein:carbohydrate ratio, generally assumed to be an index of the trophic quality of organic matter (the higher the ratio, the higher the trophic quality, Dell'Anno et al., 2002), increased during summer and autumn. The proteins responsible for this increase were partially phytoplankton-derived (the correlation between chlorophyll- $a$ and proteins was, in fact, positive and significant). However, in coastal areas affected by river discharge, the labile proteins may be tightly linked to humic acids and DOM, which are highly abundant in freshwaters. Thus, their availability for consumption is notably decreased (Keil and Kirchman, 1994). This leads to increased diagenetic processes in the sediments. The increased turbulence due to greater anthropogenic disturbance in summer-autumn may resuspend these refractory complexes, increasing the protein:carbohydrate ratio values without significantly contributing to an increase in trophic quality. In addition, the inverse correlation between the increase in the TSM flux in summer-autumn and the OM content of the sediment suggested a mobilisation towards the water column due to boat movements.

The principal stressor at Station B was the Boate Torrent. The communities were mainly composed of organic pollution and freshwater indicator species (such as Malacoceros girardi, Diopatra neapolitana, Capitella spp. and Neanthes caudata), almost exclusively in winter (95\%) and spring (98\%) when land-derived inputs were higher and salinity values were lowest (May, November and December). Notwithstanding its feeble flow, the stream strongly influenced the macrofaunal community structure, probably because of its high pollution levels as indicated by the E.B.I. index, which decreased from 1991 to 1995 (Provincia di Genova, 1996) and allowed the Capitella spp. community to develop. The dominance of Capitella spp. (representing 87\% of the total density) is a sign of pollution, in agreement with the conclusions of Belan (2003) for
Amursky Bay (Sea of Japan), Feder and Burrell (1982) for the fishing port of Dutch Harbor and Blanchard et al. (2002) for Port Valdez. The high stress level influencing the macrobenthic assemblages of Station B was confirmed by contamination indices. In fact, the marine biotic coefficient and the $\mathrm{ABC}$ curves agree with its "heavily polluted" and "severely disturbed" ecological classification.

In conclusion, the different environmental stressors identified in Rapallo Harbour strongly depended on the location of the infaunal assemblages. The main factors affecting the inner part of the harbour (public and private ports) were port structures and vessel movements, while the outer part was mainly affected by the polluted freshwater flow from the Boate Torrent. Our results also suggest that, although they didn't affect water column oxygenation, the huge loads of organic matter and the seasonal variations in the quality of the food reaching the bottom were synergic forcings affecting the benthic community of Rapallo Harbour.

\section{ACKNOWLEDGEMENTS}

The authors would like to thank N. Parodi for help in the laboratory, N. Drago for taxonomic assistance and Prof. T. Zunini Sertorio and Prof. N. Della Croce (University of Genoa) for logistical support. C. Siccardi and Prof. R. Capelli (University of Genoa) kindly provided the trace-metal data.

\section{REFERENCES}

Albertelli, G., A. Covazzi Harriague, R. Danovaro, M. Fabiano, S. Fraschetti and A. Pusceddu. - 1999. Differential responses of bacteria, meiofauna and macrofauna in a shelf area (Ligurian Sea, NW Mediterranean): role of food availability. J. Sea Res., 42: $11-26$

Belan, T.A. - 2003. Benthos abundance pattern and species composition in conditions of pollution in Amursky Bay (the Peter the Great Bay, the Sea of Japan). Mar. Pollut. Bull., 46: 1111-1119.

Blanchard, A.L., H.M. Feder and D.G. Shaw. - 2002. Long-term investigation of benthic fauna and the influence of treated ballast water disposal in Port Valdez, Alaska. Mar. Pollut. Bull., 44: 367-382.

Blanchard, A.L., H.M. Feder and D.G. Shaw. - 2003. Variations in benthic fauna underneath an effluent mixing zone at a marine oil terminal in Port Valdez, Alaska. Mar. Pollut. Bull., 46: 1583-1589.

Borja, A., J. Franco and V. Pérez. - 2000. A marine biotic index to establish the ecological quality of soft-bottom benthos within European estuarine and coastal environments. Mar. Pollut. Bull., 40: 1100-1114.

Caplat, C., H. Texier, D. Barillier and C. Lelievre. - 2005. Heavy metals mobility in harbour contaminated sediments: the case of Port-en-Bessin. Mar. Pollut. Bull., 50: 504-511. 
Carpenter, J.H. - 1965. The Chesapeake Bay Institute technique for the Winkler dissolved oxygen method. Limnol. Oceanogr., 10: 141-143.

Censi, P., S.E. Spoto, F. Saiano, M. Sprovieri, S. Mazzola, G. Nardone, S.I. Di Geronimo, R. Punturo and D. Ottonello. - 2006. Heavy metals in coastal water systems. A case study from the northwestern Gulf of Thailand. Chemosphere, 64: 1167-1176.

Clarke, K.R. - 1990. Comparison of dominance curves. J. Exp. Mar. Biol. Ecol., 138: 143-157.

Clarke, K.R. and R.M Warwick. - 1994. Changes in marine benthic communities an approach to statistical analysis and interpretation. Plymouth Marine Laboratory, Plymouth, UK (unpublished document).

Covazzi Harriague, A., C.N. Bianchi and G. Albertelli. - 2006. Soft-bottom macrobenthic community composition and biomass in a Posidonia oceanica meadow in the Ligurian Sea (NW Mediterranean). Estuar. Coast. Shelf Sci., 70: 251-258.

Danulat, E., P. Muñiz, J. García-Alonso and B. Yannicelli. - 2002. First assessment of the highly contaminated harbour of Montevideo, Uruguay. Mar. Pollut. Bull., 44: 554-565.

Dauer, D.M., M.W. Luckenbach and A.J. Rodi. - 1993. Abundance biomass comparison (ABC method): effects of an estuarine gradient, anoxic/hypoxic events and contaminated sediments. Mar. Biol., 16: 507-518.

Dell'Anno, A., M.L. Mei, A. Pusceddu and R. Danovaro. - 2002. Assessing the trophic state and eutrophication of coastal marine systems: a new approach based on the biochemical composition of sediment organic matter. Mar. Pollut. Bull., 44: 611-622.

Dubois, M., K. Gilles, J.K. Hamilton, P.A. Rebers and F. Smith. 1956. Colorimetric method for determination of sugars and related substances. Anal. Chem., 28: 350-356.

Estacio, F.J., E.M. García-Adiego, D.A. Fa, J.C. García-Gómez, J.L. Daza, F. Hortasand, J.L. Gómez-Ariza. - 1997. Ecological analysis in a polluted area of Algeciras Bay (Southern Spain): external « versus » internal outfalls and environmental implications. Mar. Pollut. Bull., 34: 780-793.

Feder, H.M. and D.C. Burrell. - 1982. Impact of seafood cannery waste on the benthic biota and adjacent waters at Dutch Harbor, Alaska. Report R82-1, Inst. Mar. Sci., Univ. Alaska, Fairbanks.

Gray, J.S. and T.H. Pearson. - 1982. Objective selection of sensitive species indicative of pollution-induced changes in benthic communities. I. Comparative methodology. Mar. Ecol. Prog. Ser., 9: 111119.

Guerra-García, J.M. and J.C. García-Gómez. - 2005. Oxygen levels versus chemical pollutants: do they have similar influence on macrofaunal assemblages? A case study in a harbour with two opposing entrances. Environ. Pollut., 135: 281-291.

Hartree, E.F. - 1972. Determination of proteins: a modification of the Lowry method that gives a linear photometric response. Analytical Biochemistry, 48: 422-427.

Je, J.G., T. Belan, C. Levings and B.J. Koo. - 2003. Changes in benthic communities along a presumed pollution gradient in Vancouver Harbour. Mar. Environ. Res., 57: 121-135.

Keil, R.G. and D.L. Kirchman. - 1994. Abiotic transformation of labile protein to refractory protein in seawater. Mar. Chem., 45: 187-196.

Lorentzen, C.J. - 1967. Determination of chlorophyll and phaeopigments spectrophotometric equations. Limnol. Oceanogr., 12: 343-346.

Morrisey, D.J., S.J. Turner, G.N. Mills, R.B. Williamson and B.E. Wise. - 2003. Factors affecting the distribution of benthic macrofauna in estuaries contaminated by urban runoff. Mar. Environ. Res., 55: 113-136.

Province of Genoa - 1996. Monitoraggio dello stato dei corsi d'acqua della provincia basato su metodi biologici. Indagini fino al 1996. Report of the Province of Genoa, $154 \mathrm{pp}$.

Rygg, B. - 1985. Distribution of species along pollution-induced diversity gradient in benthic communities in Norwegian Fjords. Mar. Pollut. Bull., 16: 469-474.

Schiff, K., D. Diehl and A. Valkirs. - 2004. Copper emissions from antifouling paint on recreational vessels. Mar. Poll. Bulletin, 48: 371-377.

Tamelander, T. and A.S. Heiskanen. - 2004. Effects of spring bloom phytoplankton dynamics and hydrography on the composition of settling material in the coastal northern Baltic Sea. J. Marine Syst., 52: 217-234.

Varela, M. and R. Prego. - 2003. Hydrography and phytoplankton in an isolated and non-pristine ria area: the A Coruña Harbour (NW Spain). Acta Oecol., 24: 113-124.

Warwick, R.M., H.M. Platt, K.R. Clarke, J. Agard and J. Gobin.1990. Analysis of macrobenthic and meiobenthic community structure in relation to pollution and disturbance in Hamilton Harbour, Bermuda. J. Exp. Mar. Biol. Ecol., 138: 119-142.

Yamaguchi, H., S. Montani, H. Tsutsumi, K. Hamada and N. Ueda. -2003. Estimation of particulate organic carbon flux in relation to photosynthetic production in a shallow coastal area in the Seto Inland Sea. Mar. Pollut. Bull., 47: 18-24.

Scient. ed.: X. Turón.

Received December 19, 2006. Accepted June 1, 2007.

Published online October 16, 2007. 